\title{
The discursive portrayals of Indonesian Muslims and Islam in the American press: A corpus-assisted discourse analysis
}

\author{
Muchamad Sholakhuddin Al Fajri \\ Faculty of Vocational Studies, Airlangga University, Jl. Dharmawangsa Dalam Selatan No.68, Airlangga, \\ Kec. Gubeng, Surabaya, Jawa Timur, Indonesia
}

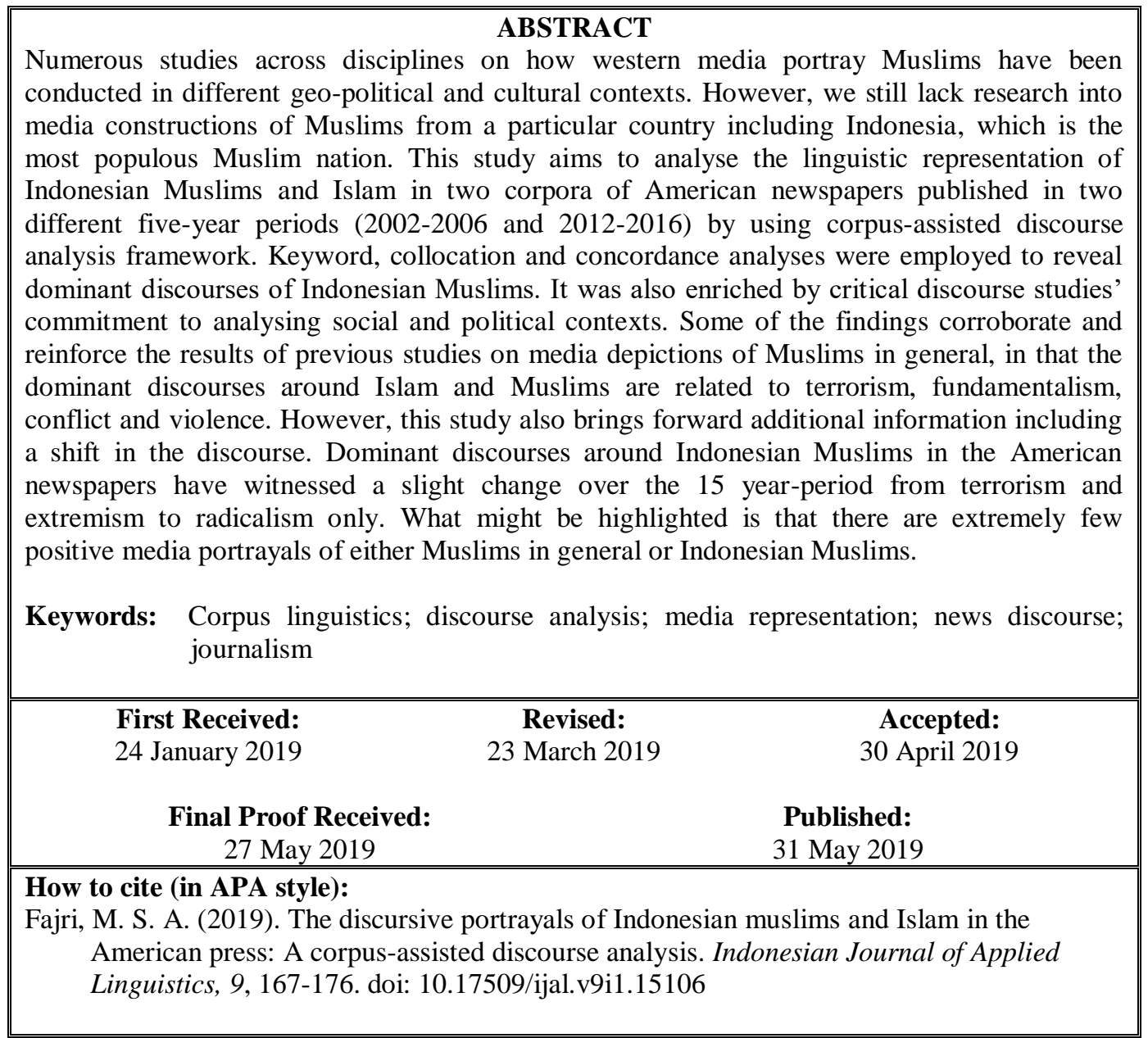

\section{INTRODUCTION}

Newspaper coverage of Muslims in western newspapers, especially British and American, has increased dramatically after the $9 / 11$ attacks (Chuang \& Roemer, 2013; Kumar, 2012). Numerous studies across disciplines on how western media portray Muslims also have been conducted in different geo-political and cultural contexts, such as in Oceanian countries (Kabir $\&$ Bourk, 2012), Europe (Steiner, 2015), Britain (Saeed, 2007) and America (Nacos \& Torres-Reyna, 2007), with various analytical tools including content analysis (Trevino, Kanso, A. M., \& Nelson, 2010), visual framing analysis (Fahmy \& Kim, 2008), and critical discourse analysis (Sharifi, Ansari, \& Asadollahzadeh, 2017). Most of these studies, nevertheless, focus more on Muslims in general. In other words, we still lack research into media constructions of Muslims from a particular country or region including Indonesia, which is the most populous Muslim nation. Islam and Muslims are more often closely connected to the Middle east, and news media tend to foreground Arab countries that are in conflict or war-torn regions, such as Iraq, Iran and Afghanistan (Ahmed \& Matthes, 2017), and overlook Indonesia which contains the most Muslims (Baker, Gabrielatos, \& McEnery, 2013). 
This study aims to investigate the construction of Indonesian Muslims and Islam in American press. Islam in American mainstream media is viewed as a homogeneous entity (Said, 2008) and stereotyped as the antithesis of America (Chuang \& Roemer, 2013). During the invasion of Iraq 2003, the relationship between Islam and America was defined in the frame "war on terror" (Shahin, 2015). Indonesian Muslims have also attracted American media attention because in 2002, a year after the pronouncement of the "war on terror", there were suicide bombings in Bali that killed many western travellers. The so-called "Jemaah Islamiyah", a terrorist group that claimed responsibility for the bombing, was also linked to al-Qaeda. Additionally, most of Indonesian Muslims considered the US invasion of Afghanistan as "morally unjustified" (Emmerson, 2002). However, Indonesia itself is considered as fully functioning democracy, which is distinct from a vast majority of Muslim countries. Besides, despite having the largest Muslim population, Indonesia is not in the list of Trump's travel ban on seven Muslim-majority countries in 2017, which may indicate that Indonesian Muslims are not seen as a threat to Americans. For these regards, it seems significant to investigate how American press depict Indonesian Muslims, and whether they have different representations from Muslims in general. As discourse is time-bound (Baker, 2006), by using corpus-assisted discourse analysis framework, I decided to examine media discourses of Indonesian Muslims published in two time periods: 2002-2006, when the Bali bombings and major terror attacks happened, and 2012-2016, a decade after the bombing.

\section{Corpus-assisted (critical) discourse analysis and newspaper discourse}

The integration between critical discourse analysis (CDA) and corpus linguistics (CL) can enable them to benefit from each other (Baker et al., 2008). Critical discourse researchers are often criticised for "cherrypicking" a few data examples that only lend weight to their initial hypotheses and suit their political agendas (Orpin, 2005, p. 38). Therefore, the application of corpus linguistic approaches that employ a large number of language data can contribute to ensure objectivity and full coverage (Baker, 2014, p. 212) and the statistical significance can help increase the level of the generality of the research findings and conclusions (Gabrielatos \& Baker, 2008). Also, CL can boost "the empirical credence" of the research by employing a wide scale of language data and lend credibility and validity to the analysis (Mautner, 2009, p. 32). CDA, on the other hand, provides a critical framework for assimilating the socio-political context into the research (Baker et al., 2008) and thus the results can be triangulated by blending corpus linguistic methods that identify typical linguistic patterns over a large collection of language data with a close qualitative reading (Baker \& Levon, 2015, p. 223).
Furthermore, this method can identify "the incremental effect of discourse" (Baker, 2006, p. 13). In the case of media discourse, it can reveal how texts of the media may be "repeatedly" framing topics and issues in a substantial period (O'Halloran, 2010). Thus, it may shed light on "the kinds of cultural and ideological meanings being circulated regularly, as well as being potentially reproduced by readers" (O`Halloran, 2010, p. 563). In this way, since discursive constructions of a social group are not formed by one text only, but through recurrent occurrences of language use, corpus linguistic approaches to CDA that can collect numerous examples of repeated phrases or grammatical constructions can reveal these cumulative effects.

Some studies have employed corpus approaches to conduct CDA/DA research in corpora of newspapers in order to investigate media representations of a particular social or a minority group. In the case of analysing a corpus of news texts published in a specific news institution, Salahshour (2016) examines the portrayal of migrants in a corpus of news articles in the New Zealand Herald. The analysis suggests that liquid metaphors such as influx(s), inflow(s) and wave(s) are not only used to represent mass immigration more negatively as suggested in the previous research (e.g. Baker \& McEnery, 2005), but also in more positive ways, reflecting its positive impact on New Zealand economy.

In terms of using two corpora of newspapers, Brindle (2016) applies a corpus-assisted discourse analysis to study the discursive representations of a protest movement called Sunflower Student Movement in two main English-language newspapers in Taiwan, The China Post and the Taipei Times.

What might be highlighted from these previous studies is that a range of corpus techniques can effectively assist (critical) discourse analysts to find patterns of particular grammatical and word choices that contribute to the representation of certain realities for the reader, suggesting that news represents particular ideologies. Also, the combined methodology could fruitfully show similarities and differences in the representation of a particular group of people in two different news corpora under investigation.

American media constructions of Islam and Muslims
A number of researchers have investigated the image of
Islam and Muslims in the American newspapers by
utilising various approaches. By using content analysis,
Trevino et al. (2010), for example, investigate Muslim
media representations in three American elite
newspapers, The New York Times, The Los Angeles
Times and The Washington Post. Their findings
demonstrate that the newspapers portray Muslims more
negatively by labelling them as terrorists,
fundamentalists and radicals. In a similar vein, Bowe,
Fahmy, and Wanta (2013) use content analysis to study
the frame of Islam in 671 news stories and editorials
published in 18 large-circulation American newspapers.


Their analysis indicates that attributes assigned to Islam are predominantly negative.

In addition, Ibrahim (2010) employs verbal and visual framing analysis to examine the image of Islam in major American news networks. Her results show that Islam is mostly represented as a violent threat or angry and violent religion. In recent time, corpusassisted critical discourse analysis was also used by Samaie and Malmir (2017) to analyse Islam and Muslim constructions in the American newspapers. They examine a 670.000-word corpus of US news articles printed between 2001 and 2015. The study suggests that Islam and Muslims are generally associated with radicalism, violence, extremist militants and a threat to the lives of innocent people.

The review of these previous studies functions to indicate that there is a pattern of negative portrayals of Muslims in American news media. It should be noted, however, that they focused more on the representation of Muslims in general. Following Samaie and Malmir (2017), this present study also used corpus-assisted critical discourse analysis to analyse Muslim portrayals in the American newspapers, but it focused on Indonesian Muslims, instead of Muslims in general.

\section{METHOD}

\section{Corpus compilation}

The news article corpora were collected from the American press within two sets of time spans: 20022006 and 2012-2016. The newspapers were downloaded from the online searchable database Lexis-Nexis, a professional web-based newspaper archive developed by RELX group. This software enables researchers to obtain news texts that contain any specific query terms. The search terms used were as follows:

Indonesian* OR Indonesia Same Sentence Muslim* OR Moslem* OR Islam

An asterisk at the end of a word acts as a wildcard, meaning that Indonesia* refers to Indonesia and Indonesians. Thus, all articles that contain the word Indonesia* and Muslim* or Moslem* or Islam in the same sentence were collated. These search terms were utilised to fully capture every reference to Indonesian Muslims as Indonesian Muslims are not always written in the exact phrase Indonesian Muslim* in the press. For example:

The majority of Indonesia's 210 million people are moderate Muslims but hardliners have managed to unsettle the government ... (Samaie \& Malmir, 2017).

In the example, the news reported Indonesian Muslims but they are referred to Muslims only in the same sentence with Indonesia*.

Furthermore, all national and regional newspapers, such as Telegraph Herald, the New York Times, Pittsburgh Press Edition, and Charleston Daily Mail, were taken into account in order to achieve a large variety of voices in the US press. Nevertheless, I also set the duplicate filter on "moderate similarity" in order to avoid inaccurate data set. The retrieved corpus of news articles in the 2002-2006 period (henceforth referred to as AME0206) is comprised of 1,514 articles with 1,355,593 words, while the 2012-2016 period corpus (henceforth referred to as AME1216) consists of 610 articles with 588,678 word-tokens.

\section{Analytical framework}

For the purpose of this study, keyword, collocate and concordance analyses were employed. AntConc 3.5.7 software (Anthony, 2018) was used to derive keyword lists of both corpora. Keywords are significant in critical discourse analysis as they can act as signposts to discourses" (Love \& Baker, 2015, p. 64). The keyword analysis was conducted by comparing the former American corpus against the latter (AME0206 vs AME1216) with the log-likelihood measure (Dunning, 1993) via the AntConc software. Then, the top 100 keywords for each list were investigated using collocate and concordance analysis. Additionally, I also carried out specific collocate analyses of words Muslim and Islamic, which are intimately related to the portrayals of Indonesian Muslims. Investigating collocates can help understand how the word is used in context and lead to the concepts of "semantic preference" (see Louw, 1993) and "discourse prosody" (see Stubbs, 2007). By using LancsBox software (Brezina et al., 2015), I arranged a span of five words on either side of the node word and a minimum of mutual information (MI) of three since according to Hunston (2002) collocates can be significant if they have an MI score of at least 3 . However, because MI score measure has a tendency to give relatively low frequency words, a collocational pair that occurs less than 15 and 10 times was excluded in the AME0206 and AME1216 respectively. This distinct setting is due to the differences in the frequency of word tokens. It should be noted that concordance analysis was also applied to supplement both keyword and collocate analyses since it allows the researcher to conduct a close reading analysis to avoid over and under interpretation of keyword and collocate lists or to do a more qualitative investigation. Also, a close study of full news texts was also conducted in some cases to look at a wider socio-political context in which the word occurs.

\section{FINDINGS AND DISCUSSION}

\section{Keyword analysis}

In the first analysis, I focused on keywords of each corpus. After generating keywords via AntConc (Anthony, 2018), I categorised them thematically by using quick concordance analysis to determine which group they best belong to. Table 1 shows lists of keywords after being classified, excluding function words, names of people, politicians, nations, and media/social media which are not significant for this study. From the list, it is obvious that in the 2002-2006 period there are many keywords related to terrorism and extremism. These include bombing, terrorist, Hambali, 
Bashir, Osama, Jemaah Islamiyah, and Al Qaeda. A quick concordance analysis of these keywords indicates that they refer to the discussion of the Bali bombings and other terror attacks committed by a group of Indonesian militant 'Muslims' in Indonesia between 2002 and 2006 (e.g. the Bali bombings, 2002 \& 2005; the Australian embassy bombing, 2004). The words al Qaeda were predominantly used to describe Jemaah Islamiyah, a militant organisation responsible for most bombings in Indonesia during 2002-2006 period (Magouirk, Atran, \& Sageman, 2008), as a group linked to al-Qaeda. This is mainly released through what Reisigl and Wodak (2001) called in discourse-historical approach (DHA) as nomination and predication strategies:

Three years ago, bombs exploded at 11 churches across Indonesia on Christmas Eve, killing 19 people and injuring around 100 . The attacks have since been blamed on the al-Qaida-linked terror group Jemaah Islamiyah. (Telegraph Herald, 22 December 2003)

Jemaah Islamiyah is closely linked to Osama bin Laden's al-Qaida network. It has been blamed for detonating the two car bombs near a Bali discotheque... (The Atlanta Journal-Constitution, 22 October 2003)

These strategies, the employment of Osama and al-Qaeda in reporting Indonesian terror attacks and in naming Jemaah Islamiyah, might be used to evoke a series of previous emotional experiences of 9/11 attack in the reader's mind through indexicality (see Silverstein, 1992) and collective memory or shared belief. This therefore could be part of legitimation through emotions (Reyes, 2011) on 'War on Terror' or future military actions.

\section{Table 1. List of keywords}

\begin{tabular}{|c|c|c|}
\hline Category & AME0206 & AME1216 \\
\hline Terror/Extremism & $\begin{array}{l}\text { Laden, bin, Baasyir, terrorism, bombing, } \\
\text { bombings, terrorist, terror, Hambali, Bashir, } \\
\text { Osama, Amrozi, bomb. }\end{array}$ & \\
\hline Terrorist Groups & Al, Jemaah, Qaeda, Islamiyah, Islamiah, Qaida. & ISIS. \\
\hline Conflict & War, military, troops, Blast. & \\
\hline Religion & & Religion, Quran, religious. \\
\hline Other Concepts & $\begin{array}{l}\text { tsunami, aid, cartoons, administration, relief, } \\
\text { defense. }\end{array}$ & $\begin{array}{l}\text { Blasphemy, sex, pageant, video, abortion, } \\
\text { fashion, Miss, minorities, migrants, boat, } \\
\text { seekers, yoga. }\end{array}$ \\
\hline
\end{tabular}

The frequent use of Jemaah Islamiah or Jemaah Islamiyah itself also can contribute to the representation of Indonesian Islam/Muslims since the terms that are taken from Arabic language mean "community of Muslims" or "Islamic community". Jemaah Islamiah/Islamiyah (JI) occurs 722 times in the AME0206 corpus and its discourse prosodies (Stubbs, 2001, p. 65) are mostly negative, collocating with terror, militant, terrorism, al-qaida-linked, and terrorist. Most Indonesian Muslims and Muslim leaders had criticized the use of this phrasing (Pavlova, 2007, p. 778) but it was continuously and uncritically utilised by the newspapers, and there was no report about the criticism in the AME0206.

On the other hand, the later corpus does not have many keywords linked to terrorism anymore, especially those referring to Bali bombings. ISIS is the only keyword correlated to terrorism. This might be expected since ISIS first appeared and began to draw attention after 2006. However, on the surface, it seems that it is not directly connected to terror attacks in Indonesia or Indonesian Islam/Muslims. Therefore, as a means of analysing this further, I conducted a close investigation on 15 random different articles across newspapers containing the word ISIS in order to find out the way Indonesian Islam/Muslims are constructed. The results indicate that in the majority of articles (13), Indonesian Islam or Muslims are not central in the story. The articles largely discuss the US foreign policy on combating ISIS and extremism. However, the portrayal of Indonesian Muslims still seems to carry negative connotations:

Like Christians and members of other non-Muslim groups, Ahmadiyya have been persecuted, attacked and killed by Islamic extremists in Pakistan, Indonesia and elsewhere. (St. Louis Post-Dispatch, 2 May 2015)

"If Indonesia is the world's largest Muslim country," he added, "then isn't it logical to think that Indonesia is what Islam looks like? Now, Indonesia is not a walk in the park for Christians and other religious minorities, but that culture looks nothing like the Islamic State." (Pittsburgh Press Edition, 25 February 2015)

The first extract above is taken from an article reporting St. Louis leader of Muslim group that opposes extremist group like ISIS. Nevertheless, persecutions and attacks on Christians and Ahmadiyya, a minority Muslim group, by 'Islamic' radicals in Indonesia are used as case examples of extremism. The second example is from an article entitled "Americans Still Confused about Forms of Islam", which commented on Obama's statement that "ISIL is not Islamic". The journalist drew heavily on LifeWay surveys and Ed Stetzer's (LifeWay's executive director) opinions in writing the news. From the extract, it can be inferred that Indonesian Muslims have made the lives of Christians and other religious minorities living in Indonesia difficult. Also, the sentence "but that culture looks nothing like the Islamic State" is likely to imply that it does not necessarily need to live in the Islamic 
State to be fundamental Muslims, which may implicitly suggest that the radical or intolerant actions against nonMuslims emanate from or taught by the faith (Islam), not wrong interpretation by ISIS. It should be noted that although the journalist applied a distancing technique by quoting voices of a social actor, s/he still has an option in determining which opinions to be included or excluded in the news article. In this respect, looking at who is quoted and cited by the newspaper can be used to obtain the perspectivization or the overall stance of an article (Reisgl \& Wodak, 2001).

Other keywords in AME0206 like tsunami, aid and relief refer to news stories about the tsunami in Aceh in 2004. In this case, the words Muslim/s and Indonesia tend to be mentioned just to describe Indonesia as a predominantly Muslim country or a country with the world's largest Muslim population, which may only serve to give background information. Cartoons refers to the issue of a Danish newspaper that published cartoons of Muhammad. The articles mainly discuss the outrage of Muslims at the publication across the world including Indonesia:

Denmark reopened its embassy in Indonesia today, more than three weeks after hard-line Muslims stormed the building and it closed amid widespread protests over the caricatures. . . (Charleston Daily Mail, 6 March 2006)

Blasphemy is a key in AME1216 corpus (occurring 183 times). The concordance analysis shows that it refers to a blasphemy case against Basuki Tjahaja Purnama (BTP) or Ahok, the Jakarta's (capital city of Indonesia) governor from 2014 to 2017. This issue is of interest to international press since the governor is a Christian and Chinese descent (see Al Fajri, 2018). This case is predominantly described as a test on religious tolerance and Indonesian pluralism and democracy, and the reports focus more on the demonstration demanding the prosecution of BTP. Also, when reporting the protest, the demonstrators are mostly labelled as hardline, hardliners, and Islamists:

The sight of tens of thousands of Islamists marching through the Indonesian capital this month, demanding that its Christian governor be jailed for blasphemy -. some even calling for his death -- (The New York Times, 14 November 2016).

Asylum, boat, seekers and refugees are keywords in the later period corpus, referring to stories about boats of asylum seekers or refugees, especially Rohingya Muslim refugees, that arrived in Indonesia. Sex, and yoga are keywords in the later corpus. Sex mainly refers to issues about Islamist groups demanding that same-sex relations and sex-outside marriage be outlawed in Indonesia. Yoga refers to news about some Muslim countries that prohibit yoga. Such representations seem congruent with Baker's (2010, p. 331) finding in the British tabloid and broadsheet newspapers that Islam is frequently defined "as a religion which is strongly characterised by the restrictions that are placed on its people". Having analysed these keywords which mainly reveal negative portrayals of Indonesian Muslims, I tried to look for other keywords that may give positive ones. However, other keywords do not appear quite crucial to the depictions of Indonesian Muslims, and do not show positive constructions.

\section{Collocation analysis}

This section focuses on the collocation analysis of the two most recurrent query terms: Muslim and Islamic. In order to reveal more portrayals of Indonesian Muslims, I decided to focus more on the top 100 adjective, noun and verb collocates that were assigned to Muslim and Islamic. Then all the collocates were categorized into several themes through manual concordance analysis. First, I analysed the word Muslim. It occurs 4076 and 1877 times in the AME0206 and AME1216 corpus respectively. Table 2 demonstrates Muslim collocate lists of both corpora after being categorized thematically, excluding names of countries or areas which are not essential for this analysis. It should be made clear that Muslim may refer to Muslims in general or Muslims in other countries. Thus, I conducted close concordance analysis before interpreting the collocates to make sure that it refers to Indonesian Muslims, and only examined in more detail collocates that are specifically connected to Indonesian Muslims. It can be seen from the table that Muslim strongly and frequently collocates with words referring to a percentage of population such as populous, large, and majority in the both corpora. These words co-occur with Muslim and other collocates such as Indonesia, country, and nation to describe Indonesia as the most populous Muslim country. Nevertheless, a close reading on the 100 random concordances of populous Muslim in the AME0206 reveals that these co-occurrences in the 2002-2006 are primarily discussed in negative descriptions, especially terrorism and extremism:

...President Megawati Sukarnoputri, who has long been criticized by some of Indonesia's neighbors and by the United States for not responding to mounting evidence that the world's most populous Muslim nation has become a haven for terrorists. (San Jose Mercury News, 17 October 2002)

On the other hand, in the AME1216 those cooccurrences mostly suggest more neutral constructions. This is likely to be influenced by the high frequency of keywords related to terrorism and extremism in the former period.

Another notable pattern is that Muslim is typically connected to types of adjective related to degree of belief such as moderate, radical, militant and hard-line. Extremists (67), fundamentalists (15), extremist (30), radicals (15), radical (57), militants (58), extremism (17) and militant (46) are collocates of Muslim in the former period, while in the later are hard-line (12) and hard-liners (12). When Muslim collocates with these types of beliefs, it occurs in the description of terror attacks, Bali bombers and other negative contexts:

A militant Muslim cleric suspected of leading a regional terror network with ties to Al Qaeda went on 
trial in Jakarta yesterday charged with plotting to overthrow the Indonesian government. (The New York Sun, 24 April 2003)

Lady Gaga is cancelling her sold-out show in Indonesia over security concerns after Muslim hard-liners threatened violence if the pop diva went ahead with her "Born This Way Ball." (Lowell Sun, 27 May 2012)

Meanwhile, moderate, which indicates positive connotation, collocates with Muslim 96 and 16 times in the AME0206 and AME1216 respectively. The concordance analysis of this connected words reveals positive depictions of Indonesian Muslims. However, the phrase primarily occurs in the news reporting radicalism and terror attacks. In this respect, the sharp decrease of the frequency of Muslim moderate in the 2012-2016 corpus may not be surprising as issues about terrorism in the newspapers also declined in this period. Also, few instances indicate that the word moderate is rather problematic:

An-Na'im said he and many of his fellow Muslims take issue with use of the phrase "moderate Muslim." "It's very insulting because it is moderate in relation to what? It defines [us] in terms of Western security interests. It's a relative term," he said. (The Atlanta JournalConstitution, 26 November 2003)
Ninety percent of the population is Muslim, but most practice a moderate, tolerant form of the faith. A small, extremist fringe has gotten more vocal -- and violent -in recent years, however, sometimes attacking Christians and members of other religious minorities with clubs and machetes. (Lowell Sun, 27 May 2012)

In the first example, the phrase moderate Muslim is criticised by An-Na'im, Candler Professor of Law at Emory University (Poole, 2003). He considered the use of such a phrase as insulting since the meaning of moderate is relative depending on Western security interests. Also, in the second example above, the conjunction but tends to imply that moderate and tolerant are not default characteristics of most Muslims since but carries the additional "conventional implicature" (Grice, 1975, pp. 44-45), indicating that the two propositions have contrasting truth values; "that is, the assertion of the second proposition is surprising, in view of the first" (Leech, 2014, p. 74). For example, if someone says "you are rich but unhappy", the speaker sees a sense of contrast between being rich and being unhappy. Additionally, it seems that the journalist in this case describes most Indonesian Muslims as moderate in order to go on and place a more focus on a violent minority.

Table 2: List of Muslim collocates

\begin{tabular}{|c|c|c|}
\hline Categories of Collocates & AME0206 & AME1216 \\
\hline Percentage of population & $\begin{array}{l}\text { Populous, second-largest, largest, large, } \\
\text { minority, majority. }\end{array}$ & $\begin{array}{l}\text { Populous, largest, majority, minority, } \\
\text { large. }\end{array}$ \\
\hline Population & $\begin{array}{l}\text { Populations, world's, population, nation, } \\
\text { world, nations, society. }\end{array}$ & $\begin{array}{l}\text { Populations, population, nation, world, } \\
\text { nations, societies, society. }\end{array}$ \\
\hline Degree of belief & $\begin{array}{l}\text { Moderates, moderate, extremists, } \\
\text { fundamentalists, extremist, radicals, } \\
\text { radical, militants, extremism, militant. }\end{array}$ & Hard-liners, hard-line, moderate. \\
\hline Conflict/terrorism & $\begin{array}{l}\text { Abubakar, Bakar, Abu, baasyir, conflict, } \\
\text { suspected, linked, protests, fight, fighting, } \\
\text { terrorists, Bashir. }\end{array}$ & Protests, violence, police. \\
\hline Islamic organisation & $\begin{array}{l}\text { Brotherhood, Nahdlatul Ulama, } \\
\text { Muhammadiyah. }\end{array}$ & Brotherhood, Ahmadiyya. \\
\hline Religion & $\begin{array}{l}\text { Cleric, clerics, Ramadan, Sunni, Christian, } \\
\text { holy, Hindu, secular, Jewish, faith, pope, } \\
\text { religious, Christians. }\end{array}$ & $\begin{array}{l}\text { Holy, clerics, Buddhist, Jewish, } \\
\text { Ramadan, Sunni, conservative, Christian, } \\
\text { secular, Christians, faith, religious, } \\
\text { Islamic. }\end{array}$ \\
\hline Organization/collective & $\begin{array}{l}\text { Organizations, association, community, } \\
\text { groups, organization, council. }\end{array}$ & $\begin{array}{l}\text { Communities, community, organizations, } \\
\text { groups, member, organization, group, } \\
\text { members. }\end{array}$ \\
\hline Ethnicity/race/nationality & Arab, Indonesians, western. & $\begin{array}{l}\text { Rohingya, ethnic, Americans, Arab, } \\
\text { western, Indonesian, American. }\end{array}$ \\
\hline Governance & Leaders, parties, democracy, leader, head. & Leaders, Obama, trump, president. \\
\hline
\end{tabular}

Like in the keyword analysis, Muslim also recurrently collocates with words referring to conflict or terrorism issues such as Baasyir, conflict, protests, terrorists and violence in the both corpora. The words linked and protests may not immediately fit into the category of "conflict/terrorism", but when I considered the context where they were used in news reports, they were likely to be related to conflict/terrorism topics:

Muslim protests spread: Violent protests over an antiIslam film that critically depicts the prophet Mohammed showed no sign of ebbing as riots spread to Indonesia . . . (The New York Post, 18 September 2012)
The next collocates are in the category of "religion", referring to religious beliefs and terms related to religion or Islam. The most frequent collocates in the category are the words cleric and Christian in the AME0206 and AME1216 respectively. When Muslim collocates with cleric, the connected word primarily refers to the radical Muslim cleric Abu Bakar Baasyir, bringing about negative constructions of Muslim clerics. When Christian collocates with Muslim, they do not mainly appear in neutral contexts or in balanced discussions about religious matters and 
relationship between religions, but more in discussions related to conflict, with Indonesian Muslims as the agents of violent actions:

In August 2011, for example, Muslim militants burned down three Christian churches on Sumatra. No one was charged and officials have prevented the congregations from rebuilding their churches. (The New York Times, 22 May 2012).

Muslim also frequently collocates with organizations, community, and groups, indicating collectivisation and differentiation of Muslims. The most recurrent collocate in this category in the former corpus is the word groups (101). When it refers to Indonesian Muslim groups, the term tends to attract extremism and militancy collocates. On the other hand, the most frequent collocate in the later corpus is community (58). However, the term Muslim community in this period mostly refers to non-Indonesian Muslim community such as Rohingya in Myanmar and Ahmadiyah in India.

In the governance category, unlike Baker et al.'s (2013) finding that Muslim leaders are canonically constructed in terms of their disapproval of something or their condemnations and anger, in this corpora Indonesian Muslim leaders are regularly represented in a more positive way. Indeed, the most common adjective that modifies Muslim leaders is moderate and prominent. Also, it is interesting to note that Obama (56) and Trump (11) are collocates in the later period.
The collocate Obama refers to the rumour that Obama is a Muslim and born in Indonesia, while Trump indicates news about Trump that bans Muslim immigrants.

Turning to the word Islamic, it can be seen from table 3 that the word Islamic tends to hold a more negative discourse prosody of fundamentalism in all corpora (with collocates like extremist, extremism, radicalism). It is frequently and strongly linked with lexis referring to conflict and terrorism topoi. Again, this might be affected by the frequent occurrences of news reports discussing terror attacks in Indonesia. This finding echoes the conclusion by Baker et al. (2013) that compared with Muslim(s), Islamic is more strongly and recurrently associated with religious and political radicalism, militancy and terror. In addition, it is essential to note the emergence of a unique collocates, protests (19), in this category in the later corpus. This collocate refers to protests staged by Islamic hardliners or hardline Islamic groups, suggesting that news stories about civil conflict especially involving Islamic groups have increased and become of interest to news agencies.

A second notable pattern in all corpora involves Islamic collocating with nouns that reference Islam as a political entity, with state, law, sharia or shariah as the most frequent. Islamic law is described as strict and typically discussed with issues of terrorists, and hardline or Islamist groups that insist on imposing the law (with collocates like strict, implement, impose).

Table 3. List of Islamic collocates

\begin{tabular}{|c|c|c|}
\hline Collocates & AME0206 & AME1216 \\
\hline Degree of belief & $\begin{array}{l}\text { Radicalism, militancy, fundamentalism, } \\
\text { radicals, extremism, fundamentalist, militant, } \\
\text { extremists, radical, militants, hard-line, } \\
\text { extremist, moderate. }\end{array}$ & $\begin{array}{l}\text { Hard-liners, hard-line, extremists, } \\
\text { extremism, militants, militant, moderate, } \\
\text { radical. }\end{array}$ \\
\hline Population & World, society. & World, society. \\
\hline Conflict and terrorism & $\begin{array}{l}\text { Jemaah Islamiyah, Jemaah Islamiah, jihad, } \\
\text { network, links, linked, suspected, baasyir, } \\
\text { threat, fighting, bashir, arrested, terrorists, } \\
\text { terrorist. }\end{array}$ & $\begin{array}{l}\text { Protests, threat, fighting, violent, terrorism, } \\
\text { attacks, terrorist, ISIS, attack, violence, } \\
\text { war, police. }\end{array}$ \\
\hline Islamic organisation & $\begin{array}{l}\text { Moro Islamic Liberation Front, Islamic } \\
\text { Defenders Front. }\end{array}$ & Islamic Defenders Front. \\
\hline Religion & $\begin{array}{l}\text { Sharia, shariah, caliphate, clerics, secular, } \\
\text { cleric, faith, religious, Christians. }\end{array}$ & $\begin{array}{l}\text { Shariah, conservative, sharia, faith, } \\
\text { religious, Islamic, Muslims, Islam, Muslim. }\end{array}$ \\
\hline Organization / collective & $\begin{array}{l}\text { Group, groups, organization, organizations, } \\
\text { community, members. }\end{array}$ & $\begin{array}{l}\text { groups, organizations, organization, group, } \\
\text { members. }\end{array}$ \\
\hline Education & $\begin{array}{l}\text { Boarding, scholar, art, studies, schools, } \\
\text { university, conference. }\end{array}$ & $\begin{array}{l}\text { Teachings, scholars, studies, university, } \\
\text { professor, schools, school. }\end{array}$ \\
\hline Governance & $\begin{array}{l}\text { Law, parties, laws, party, leaders, leader, } \\
\text { head, political. }\end{array}$ & law, parties, leaders, political, government \\
\hline
\end{tabular}

Furthermore, Islamic also heavily collocates with defender/s and front in all corpora, referring to the Islamic Defenders Front (an Indonesian Islamic organisation). Discourses around the group are terribly negative. It is described as radical, militant, hardline, vigilante, thuggish, notorious, violent and threatening. Islamic and group* are also recurrently linked in the both corpora. Collocation analysis of this connected term shows that it carries a more negative prosody. It is typically attributed to hardline, radical and militant in both corpora:

According to human rights organizations and various surveys, religious intolerance is on the rise in Indonesia, at least partly because of the growing influence of radical Islamic groups that use street protests and acts of violence to support their aims. (The New York Times, 4 May 2014).

The extract above is representative of this pattern. It is taken from an article reporting the rise of religious 
intolerance in Indonesia. In this case, the journalist applied a distancing technique to legitimaze the claim by using voices of experts (Reyes, 2011).

Another collocate that is significant and occurs in all corpora is boarding, which refers to Islamic boarding schools. Boarding collocates with Islamic 51 times in the AME0206 corpus. A close investigation reveals that 34 of 51 occurrences suggest negative representations of Islamic boarding school/s. They are described as hardline, militant, notorious and radical, and the most constructions are as a hiding place and a breeding or recruiting ground for terrorists:

In the early 1970's, Mr. Bashir was co-founder of an Islamic boarding school in Ngruki, in central Java, which has been, and remains, a breeding ground for radicals. Nearly all of the men who have been charged in connection with the Bali bombing graduated from that school. (The New York Times, 3 September 2003)

In the 2012-2016 corpus, Islamic also collocates with school $^{*} 21$ times. However, concordance analysis suggests that 16 examples show more neutral or positive construction, although 4 still depict Islamic schools as radicals.

\section{CONCLUDING REMARKS}

This research has investigated the construction of Indonesian Muslims in the American newspapers in two different periods (2002-2006 and 2012-2016), contributing towards a body of research investigating media constructions of Muslims and Islam. Some of the results corroborate and reinforce the findings of the previous studies on media depictions of Muslims in general, in that the dominant discourse around Islam and Muslims are related to terrorism, fundamentalism, conflict and violence. However, this study also brings forward additional information including a shift in the discourse. In the 2002-2006 period, Indonesian Muslims are predominantly constructed in the context of terrorism, particularly the Bali bombing attacks. In the later period, terrorism-related keywords and collocates decreased dramatically, while keywords and collocates related to civil conflict increased. This suggests a stable discourse connecting Muslims to conflict. The construction of Indonesian Muslims as extremists or fundamentalist, on the other hand, seem unchanged. Although American newspapers canonically portray Indonesian Muslims as moderate, the term is mainly used in the discussion of terrorism and extremism, thus serving to question the moderation of Indonesia. What might be highlighted is that there are extremely few positive media portrayals of either Muslims in general or Indonesian Muslims. A startling result of such recurrent and dominant negative framing is a negative stereotype of Muslims and Islam since news discourse has the ability to influence and form people's ideas and behaviours (Bednarek \& Caple, 2012). Additionally, the frequent and continuous use of the phrases "Islamic terrorism", "Islamic terrorists", "Islamic fundamentalists", "Muslim radicals", "hard-line
Muslims" may prime readers to think that Islam and Muslims are all about conflict and violence. As Hoewe and Bowe (2018) also points out, the use of radical Islam in the US news media that is linked to terrorism and other negative stories can make American readers difficult to disentangle the two concepts. Thus, the journalists should have more mindful use of language and consider seriously whether the words "Islamic" and "Muslim" or the religious orientation of people is always required to be included in such negative terms and contexts.

\section{REFERENCES}

Ahmed, S., \& Matthes, J. (2017). Media representation of Muslims and Islam from 2000 to 2015: A metaanalysis. International Communication Gazette, 79(3), 219-244. doi: 10.1177/1748048516656305

Al Fajri, M. S. (2018). The Representation of a blasphemy protest in Jakarta in local and international press. Indonesian Journal of Applied Linguistics, 7(3), 705. doi: 10.17509/ijal.v7i3.9821

Anthony, L. (2018). AntConc (3.5.7) [Computer Software]. Tokyo, Japan: Waseda University. Retrieved from http://www.laurenceanthony.net/software

Baker, P. (2006). Using Corpora in Discourse Analysis. London: Continuum.

Baker, P. (2010). Representations of Islam in British broadsheet and tabloid newspapers 1999-2005. Journal of Language and Politics, 9(2), 310-338. doi: 10.1075/jlp.9.2.07bak

Baker, P. (2014). 'Bad wigs and screaming mimis': Using corpus-assisted techniques to carry out critical discourse analysis of the representation of trans oeople in the British press. In C. Hart \& P. Cap (Eds.), Contemporary Critical Discourse Studies (pp. 211-235). London: Bloomsbury.

Baker, P., Gabrielatos, C., Khosravinik, M., Krzyzanowski, M., McEnery, T., \& Wodak, R. (2008). A useful methodological synergy? Combining critical discourse analysis and corpus linguistics to examine discourses of refugees and asylum seekers in the UK press. Discourse \& Society, 19(3), 273-306. doi: $10.1177 / 0957926508088962$

Baker, P., Gabrielatos, C., \& McEnery, T. (2013). Discourse Analysis and Media Attitudes: The Representation of Islam in the British Press Cambridge: Cambridge University Press.

Baker, P., \& Levon, E. (2015). Picking the right cherries? A comparison of corpus-based and qualitative analyses of news articles about masculinity. Discourse \& Communication, 9(2), 221-236. doi: $10.1177 / 1750481314568542$

Baker, P., \& McEnery, T. (2005). A corpus-based approach to discourses of refugees and asylum seekers in UN and newspaper texts. Journal of Language and Politics, 4(2), 197-226. doi: 10.1075/jlp.4.2.04bak 
Bednarek, M., \& Caple, H. (2012). News Discourse. London: Continuum.

Bowe, B. J., Fahmy, S., \& Wanta, W. (2013). Missing religion: Second level agenda setting and Islam in American newspapers. International Communication Gazette, 75(7), 636-652. doi: $10.1177 \% 2 \mathrm{~F} 1748048513482544$

Brezina, V., McEnery, T., \& Wattam, S. (2015). Collocations in context: A new perspective on collocation networks. International Journal of Corpus Linguistics, 20(2), 139-173. doi: 10.1075/ijcl.20.2.01bre

Brindle, A. (2016). A corpus analysis of discursive constructions of the Sunflower Student Movement in the English- language Taiwanese press. Discourse \& Society, 27(1), 3-19. doi: 10.1177/0957926515605957

Chuang, A., \& Roemer, R. C. (2013). The immigrant Muslim American at the boundary of insider and outsider: Representations of Faisal Shahzad as "Homegrown" terrorist. Journalism and Mass Communication Quaterly, 90(1), 89-107. doi: $10.1177 / 1077699012468740$

Dunning, T. (1993). Accurate Methods for the Statistics of Surprise and Coincidence. Computational Linguistics, 19(1), 61-74.

Emmerson, D. K. (2002). Whose Eleventh? Indonesia and the United States since 11 September. The Brown Journal of World Affairs, 9(1), 115-126.

Fahmy, S., \& Kim, D. (2008). Picturing the iraq war: Constructing the image of war in the British and US press. International Communication Gazette, 70(6), 443-462. doi: 10.1177/1748048508096142

Gabrielatos, C., \& Baker, P. (2008). Fleeing, sneaking, flooding: A corpus analysis of discursive constructions of refugees and asylum seekers in the UK press, 1996-2005. Journal of English Linguistics, 36(1), 5-38. doi: $10.1177 / 0075424207311247$

Grice, H. P. (1975). Logic and Conversation. In P. Cole \& J. L. Morgan (Eds.), Syntax and Semantics 3: Speech Acts (pp. 41-58). New York: Academic Press.

Hoewe, J., \& Bowe, B. J. (2018). Magic words or talking point? The framing of 'radical Islam' in news coverage and its effects. Journalism. doi: $10.1177 / 1464884918805577$

Hunston, S. (2002). Corpora in Applied Linguistics. Cambridge: Cambridge University Press.

Ibrahim, D. (2010). The framing of Islam on network news following the September 11th attacks. International Communication Gazette, 72(1), 111125. doi: $10.1177 / 1748048509350342$

Kabir, S. N., \& Bourk, M. (2012). Representing Islam and Muslims in New Zealand newspapers. Journal of Muslim Minority Affairs, 32(3), 324-338. doi: 10.1080/13602004.2012.727293

Kumar, D. (2012). Islamophobia and the Politics of Empire. London: Haymarket.
Leech, G. N. (2014). The Pragmatics of Politeness. Oxford: Oxford University Press.

Louw, B. (1993). Irony in the Text or Insincerity in the Writer? The Diagnostic Potential of Semantic Prosodies. In M. Baker, G. Francis, E. TogniniBonelli, \& J. M. Sinclair (Eds.), Text and Technology (pp. 157-176). Amsterdam: John Benjamins.

Love, R., \& Baker, P. (2015). The hate that dare not speak its name? Journal of Language Aggression and Conflict, 3(1), 57-86. doi: 10.1075/jlac.3.1.03lov

Magouirk, J., Atran, S., \& Sageman, M. (2008). Connecting terrorist networks. Studies in Conflict \& Terrorism, 31(1), 1-16. doi: $10.1080 / 10576100701759988$

Mautner, G. (2009). Corpora and critical discourse analysis. In P. Baker (Ed.), Contemporary Corpus Linguistics (pp. 32-46). London: Continuum.

Nacos, B. L., \& Torres-Reyna, O. (2007). Fueling our Fears: Stereotyping, Media Coverage, and Public Opinion of Muslim Americans. Lanham, MD: Rowman \& Littlefield.

O`Halloran, K. (2010). How to use corpus linguistics in the study of media discourse. In A. O'Keeffe \& M. McCarthy (Eds.), The Routledge Handbook of Corpus Linguistics (pp. 563-577). London: Routledge.

Orpin, D. (2005). Corpus linguistics and critical discourse analysis: Examining the ideology of sleaze. International Journal of Corpus Linguistics, 10(1), 37-61. doi: 10.1075/ijcl.10.1.03orp

Pavlova, E. (2007). From a counter-society to a counterstate movement: Jemaah Islamiyah according to PUPJI. Studies in Conflict \& Terrorism, 30(9), 777-800. doi: 10.1080/10576100701501984

Poole, S. M. (2003, November 23). Debate rages within Islam over faith. The Atlanta Journal-Constitution, p. $1 \mathrm{~F}$.

Reisigl, M., \& Wodak, R. (2001). Discourse and Discrimination : Rhetorics of Racism and Antisemitism. London: Routledge.

Reyes, A. (2011). Strategies of legitimization in political discourse: From words to actions. Discourse \& Society, 22(6), 781-807. doi: $10.1177 / 0957926511419927$

Saeed, A. (2007). Media, racism and islamophobia: The representation of Islam and Muslims in the media. Sociology Compass, 1(2), 443-462. doi: 10.1111/j.1751-9020.2007.00039.x

Said, E. W. (2008). Covering Islam: How the Media and the Experts Determine How We See the Rest of the World. New York: Random House.

Salahshour, N. (2016). Liquid metaphors as positive evaluations: A corpus-assisted discourse analysis of the representation of migrants in a daily New Zealand newspaper. Discourse, Context \& Media, 13, 73-81. doi: 10.1016/j.dcm.2016.07.002 
Samaie, M., \& Malmir, B. (2017). US news media portrayal of Islam and Muslims: A corpus-assisted critical discourse analysis. Educational Philosophy and Theory, 49(14), 1351-1366. doi: $10.1080 / 00131857.2017 .1281789$

Shahin, S. (2015). Unveiling the American-Muslim press: News agendas, frames, and functions. Journalism, 16(7), 884-903. doi: $10.1177 / 1464884914545376$

Sharifi, M., Ansari, N., \& Asadollahzadeh, M. (2017). A critical discourse analytic approach to discursive construction of Islam in Western talk shows: The case of CNN talk shows. International Communication Gazette, 79(1), 45-63. doi: $10.1177 / 1748048516656301$

Silverstein, M. (1992). The indeterminacy of contextualization: When is enough enough? In P. Auer \& A. D. Luzio (Eds.), The contextualization of language (pp. 55-76). Philadelphia: John Benjamins.
Steiner, K. (2015). Images of Muslims and Islam in Swedish Christian and secular news discourse. Media, War \& Conflict, 8(1), 20-45. doi: 10.1177/1750635214531107

Stubbs, M. (2001). Words and Phrases : Corpus Studies of Lexical Semantics. London: Blackwell Publishers.

Stubbs, M. (2007). Quantitative data on multi-word sequences in English: The case of the word world. In M. Hoey (Ed.), Text, Discourse and Corpora: Theory and Analysis (pp. 163-189). London: Continuum.

Trevino, M., Kanso, A. M., \& Nelson, R. A. (2010). Islam through editorial lenses: How American elite newspapers portrayed Muslims before and after September 11, 2001. Journal of Arab \& Muslim Media Research, 3(1-2), 3-17. doi: 10.1386/jammr.3.1-2.3_1 